\title{
Genetic variation of ITGB3 is associated with Autism Spectrum Disorders (ASD) in South Indian children
}

\author{
Femina KMB Nair ${ }^{1 *}$, PA Suresh², Moinak Banerjee ${ }^{1}$ \\ From International Conference on Human Genetics and 39th Annual Meeting of the Indian Society of \\ Human Genetics (ISHG) \\ Ahmadabad, India. 23-25 January 2013
}

\section{Background}

Autism spectrum disorders (ASDs) are a group of developmental disabilities that can cause significant social, communication and behavioral challenges in children. Genetic factors contribute significantly to ASD. ITGB3 encodes integrin $\beta 3$. This cell adhesion molecule has been implicated as a modulator of serotonergic systems as well as in regulation of synaptic plasticity and maturation. In the brain, integrin $\beta 3$ couples to integrin $\alpha \mathrm{v}$ to form a functional receptor, making integrin $\alpha v \beta 3$ an interesting target for regulation of neural 5-HT systems. The aim of this study was to investigate the potential associations of single-nucleotide polymorphisms (SNPs) of the integrin gene with Autism Spectrum Disorder (ASD).

\section{Material and methods}

Hundred and twenty five patients with ASD and 210 healthy volunteers were recruited. Four SNPs of Integrin genes were analyzed by direct sequencing and polymerase chain reaction-restriction fragment length polymorphism genotyping.

\section{Results}

We detected significant allelic and genotypic associations with rs3809865 (Allelic and genotypic $\mathrm{p}$ value $=0.0089$, 0.0044 ). Haplotypic association involving risk allele was observed in two, three and four locus. This 3'UTR SNP would decrease/break or enhance/create miRNA-mRNA

\footnotetext{
* Correspondence: femina@rgcb.res.in

'Human Molecular Genetics laboratory, Rajiv Gandhi centre for

Biotechnology, Thiruvananthapura, India

Full list of author information is available at the end of the article
}

binding sites and thus affect the expression of host genes in the brain.

\section{Conclusions}

Our finding identified the possible function of this SNP locus, and provides the basis for subsequent functional research.

\section{Authors' details \\ ${ }^{1}$ Human Molecular Genetics laboratory, Rajiv Gandhi centre for Biotechnology, Thiruvananthapura, India. ${ }^{2}$ ICCONS, Shoranur, India.}

Published: 21 January 2014

doi:10.1186/1755-8166-7-S1-P109

Cite this article as: Nair et al:: Genetic variation of ITGB3 is associated with Autism Spectrum Disorders (ASD) in South Indian children. Molecular Cytogenetics 2014 7(Suppl 1):P109.

Submit your next manuscript to BioMed Central and take full advantage of:

- Convenient online submission

- Thorough peer review

- No space constraints or color figure charges

- Immediate publication on acceptance

- Inclusion in PubMed, CAS, Scopus and Google Scholar

- Research which is freely available for redistribution 